\title{
FAKTOR-FAKTOR YANG MEMPENGARUHI NIAT MENABUNG DI BANK SYARIAH
}

\author{
Mia Muktiana Banowati \& Maimun Sholeh \\ Universitas Negeri Yogyakarta, Indoensia \\ myamuktiana@gmail.com,maimunsholeh@uny.ac.id
}

\begin{abstract}
Abstrak: Penelitian ini bertujuan mengetahui pengaruh pemahaman prinsip tabungan syariah, tingkat religiusitas, faktor sosial budaya, persepsi tentang Bank Syariah baik secara parsial maupun simultan terhadap niat menabung di Bank Syariah pada Mahasiswa Pendidikan Ekonomi Angkatan Tahun 2014 Universitas Negeri Yogyakarta. Jumlah anggota populasi yaitu sebanyak 69 Mahasiswa S1 Program Studi Pendidikan Ekonomi Angkatan Tahun 2014. Dengan teknik analisis regresi linear berganda, menunjukkan bahwa terdapat (1) pengaruh positif pemahaman prinsip tabungan syariah terhadap niat menabung di Bank Syariah; (2) pengaruh positif tingkat religiusitas terhadap niat menabung di Bank Syariah; (3) pengaruh positif faktor sosial budaya terhadap niat menabung di Bank Syariah; (4) pengaruh positif persepsi tentang Bank Syariah terhadap niat menabung di Bank Syariah; dan (5) terdapat pengaruh pemahaman prinsip tabungan syariah, tingkat religiusitas, faktor sosial budaya, persepsi tentang Bank Syariah secara simultan terhadap niat menabung di Bank Syariah pada Mahasiswa Pendidikan Ekonomi Angkatan Tahun 2014.
\end{abstract}

Kata kunci: Niat, Pemahaman, Religiusitas, Sosial Budaya, Persepsi.

\section{FACTORS AFFECTING SAVING INTENTION IN ISLAMIC BANK}

\begin{abstract}
This study aims to determine the effect of understanding the principles of sharia savings, the level of religiosity, socio-cultural factors, perceptions of Islamic banks both partially and simultaneously towards the intention to save at a Sharia Bank for the 2014 Yogyakarta State University Economic Education Students. The number of members of the population is as much as 69 S1 students of the 2014 Economic Education Study Program. With multiple linear regression analysis techniques, it shows that there are (1) positive influences on understanding the principle of sharia savings towards the intention to save in Islamic banks; (2) a positive influence on the level of religiosity on the intention to save in Islamic banks; (3) the positive influence of socio-cultural factors on the intention to save in Islamic banks; (4) the positive influence of perceptions of Islamic banks on the intention to save in Islamic banks; and (5) there is an effect of understanding the principles of sharia savings, the level of religiosity, socio-cultural factors, perceptions of Islamic banks simultaneously towards the intention to save in a Sharia Bank for 2014 Economic Education Students.
\end{abstract}

Keyword: Intention, Understanding, Religiosity, Socio-Cultural, Perception.

\section{PENDAHULUAN}

Seiring dengan berjalannya waktu, berbagai kegiatan ekonomi semakin berkembang ditambah lagi dengan teknologi yang semakin modern. Semua kegiatan ekonomi menjadi tidak terbatas dengan tempat dan waktu tidak terkecuali kegiatan perbankan. Hampir seluruh kegiatan ekonomi saat ini menggunakan jasa perbankan seperti penyimpanan dan pembiayaan. Bahkan, tercatat dari tahun ke tahun kebutuhan pembiayaan mengalami peningkatan sehingga semakin banyak pula berdirinya lembaga keuangan bank maupun lembaga keuangan non bank, baik milik pemerintah maupun swasta. Masyarakat dari berbagai profesi saat ini pasti telah menggunakan jasa perbankan baik dalam bentuk pembiayaan maupun investasi/simpanan. Adanya produk lembaga keuangan memang sangat membantu dalam menunjang kehidupan sehari-hari bagi mahasiswa. 
Dalam pemanfaatan produk perbankan untuk meningkatkan pertumbuhan perekonomian Indonesia, Presiden Jokowi menargetkan pada tahun 2019, sebanyak 75\% penduduk di Indonesia memiliki tabungan. Hal ini disebabkan tabungan nasional memiliki peran penting dalam perekonomian. Berdasarkan statistik perbankan syariah oleh Otoritas Jasa Keuangan (OJK) periode September 2017, menunjukkan bahwa kegiatan usaha Bank Umum Syariah di Indonesia terdiri dari penghimpunan dana sebesar Rp 232,249 Triliun dan pembiayaan bagi hasil sebesar Rp 65,897 Triliun. Kegiatan penghimpunan dana tersebut terdiri dari dana simpanan wadi'ah sebesar Rp 32,582 Triliun dan dana investasi non profit sharing (mudharabah) sebesar Rp 199,767 Triliun. Selain itu, kegiatan pembiayaan bagi hasil tersebut, masing-masing terdiri dari pembiayaan bagi hasil kepada pihak ketiga bukan bank yaitu mudharabah sebesar $\mathrm{Rp}$ 7,434 Triliun dan musyarakah sebesar Rp 58,642 Triliun serta ke bank lain yaitu mudharabah Rp 495 Milyar dan musyarakah sebesar Rp 45 Milyar. Hal ini berarti kegiatan usaha menghimpun dana (wadi'ah dan mudharabah) merupakan yang paling diminati oleh masyarakat daripada produk pembiayaan bagi hasil (mudharabah dan musyarakah).

Perkembangan dan pertumbuhan perbankan syariah yang pesat belum cukup untuk mendominasi kejayaan perbankan syariah.Berdasarkan data dari siaran pers oleh Otoritas Jasa Keuangan (OJK) pada 27 Oktober 2017, tercatatbahwa market share perbankan syariah sebesar $5,44 \%$ dari target sebesar 5\%. Namun jika dibandingkan dengan perbankan konvensional, market share perbankan syariah masih jauh lebih rendah. Selain itu, berdasarkan statistik perbankan syariah oleh OJK periode September 2017,total pembiayaan senilai Rp 186,77 triliun atau hanya tumbuh $8,22 \%$ secara tahunan dengan target sebesar $11,79 \%$. Hal ini menunjukkan bahwa perbankan syariah belum dapat mencapai target.

Melalui perbandingan data kegiatan usaha bank umum konvensional dan bank umum syariah pada statistik perbankan Indonesia oleh OJK periode September 2017, juga dapat diketahui bahwa kegiatan usaha bank umum konvensional lebih tinggi dibandingkan dengan bank umum syariah. Masih banyak masyarakat Indonesia yang lebih memilih menggunakan bank konvensional dalam kehidupan sehari-harinya walaupun mayoritas penduduk di Indonesia beragama Islam. Hal ini disebabkan persepsi masyarakat terhadap bank konvensional sudah tertanam, sehingga cukup sulit menumbuhkan persepsi baru mengenai Bank Syariah termasuk mahasiswa. Selain itu, seharusnya agama (religiusitas) dapat menjadi faktor yang mempengaruhi masyarakat dalam mengambil keputusan menggunakan produk Bank Syariah mengingat ketentuan yang terdapat dalam ajaran agama.

Mahasiswa di Yogyakarta, khususnya Mahasiswa Pendidikan Ekonomi Angkatan Tahun 2014 Universitas Negeri Yogyakarta dalam survey awal penelitian menunjukkan bahwa mayoritas Mahasiswa tersebut belum memiliki niat menabung di Bank Syariah. Padahal, sebagian besar dari mereka sudah menempuh mata kuliah berbasis kesyariahan seperti Ekonomi Islam, Fiqih Muamalah, serta Bank dan Lembaga Keuangan Syariah yang memang baru diadakan pada mahasiswa angkatan tahun 2014. Mahasiswa penempuh mata kuliah berbasis kesyariahan tersebut seharusnya memiliki pemahaman lebih baik mengenai Bank Syariah jika dibandingkan dengan mahasiswa lainnya yang tidak mendapatkan mata kuliah berbasis kesyariahan.

Berdasarkan hasil observasi awal berupa pengajuan pertanyaan pada 35 Mahasiswa Pendidikan Ekonomi angkatan tahun 2014, sebanyak 18 mahasiswa menyatakan bahwa mereka tidak memiliki niat menabung di Bank Syariah, 8 mahasiswa masih ragu-ragu, serta 9 mahasiswa memiliki niat menabung di Bank Syariah. Padahal, seluruh mahasiswa tersebut beragama Islam dan memiliki pemahaman mengenai prinsip operasional bank umum syariah. Selain itu, dalam pra penelitian tersebut juga diketahui bahwa mayoritas mahasiswa yang tidak memiliki niat menabung 
di Bank Syariah dilatarbelakangi oleh faktor sosial budaya dan persepsi yang masih belum cukup baik tentang Bank Syariah.

Dalam teori perilaku terencana oleh Ajzen (1991), faktor penentu terpenting pada perilaku seseorang adalah niat untuk melakukan perilaku tersebut. Seorang individu mungkin memiliki kendali sepenuhnya ketika tidak terdapat hambatan apapun untuk menampilkan suatu perilaku. Namun, dalam keadaan ekstrim dapat terjadi sebaliknya, seorang individu bisa saja sama sekali tidak terdapat kemungkinan untuk mengendalikan suatu perilaku karena tidak adanya kesempatan, sumber daya, atau ketrampilan. Menurut Ajzen (1991), niat diasumsikan sebagai penangkapan faktor-faktor motivasional yang mempengaruhi perilaku serta yang mengindikasikan seberapa keras orang bersedia untuk mencoba dan berapa banyak upaya yang mereka rencanakan untuk dikerahkan dalam rangka untuk melakukan perilaku. Niat untuk terlibat dalam perilaku tertentu dipengaruhi oleh sikap terhadap perilaku (attitude toward behavior), norma subyektif (subyective norm) yang dapat meliputi faktor sosial budaya, serta kontrol perilaku yang dirasakan (perceived behavioral control) yang dapat berupa pemahaman/ pengetahuan, tingkat religiusitas, dan persepsi.

Pemahaman mengenai prinsip tabungan Bank Syariah adalah mengerti atau mengetahui benar mengenai prinsip suatu simpanan pada Bank Syariah (wadi'ah dan mudharabah). Selain itu, menurut Glock dan Stark (dalam Ancok dan Suroso, 1995) terdapat lima dimensi yang dapat mengukur tingkat religiusitas yaitu dimensi keyakinan (the ideological dimension), dimensi praktik ibadah (the ritualistic dimension), dimensi ihsan dan penghayatan (the experiental dimension), dimensi pengetahuan agama (the intellectual dimensions), dan dimensi pengalaman atau konsekuensi (the consequential dimensions).

Menurut Kotler (2009) faktor sosial dan budaya dapat mempengaruhi seseorang dalam melakukan pembelian. Dalam faktor sosial tedapat beberapa hal yaitu kelompok referensi/ acuan, keluarga, serta peran dan status sosial. Selain itu, terdapat tiga dimensi dari budaya yaitu Budaya, sub-budaya, dan kelas sosial. Terdapat pula faktor-faktor yang mempengaruhi persepsi seseorang (Toha, 2003), diantaranya yaitu faktor internal (meliputi perasaan, sikap dan kepribadian, prasangka, keinginan, perhatian, proses belajar, kebutuhan dan sebabainya), serta faktor eksternal (meliputi latar belakang keluarga, informasi yang diperoleh, , keberlawanan, ketidak asingan suatu objek, dan lainnya).

\section{METODE}

Penelitian ini merupakan jenis penelitian ex post facto dan penelitian asosiatif kausal. Yang dimaksud dengan penelitian ex post facto ini adalah penelitian di mana variabel-variabel bebas yang mempengaruhi variabel terikat telah terjadi ketika penelitian dilakukan, sehingga peneliti tidak dapat melakukan manipulasi dan kontrol terhadap variabel bebas tersebut (Arikunto, 2013). Penelitian ini termasuk ke dalam penelitian asosiatif kausal karena untuk melihat hubungan sebab akibat antar variabel-variabel penelitian dan menguji hipotesis yang telah dirumuskan sebelumnya. Selain itu, karena penelitian ini mengambil seluruh anggota populasi sebagai subjek penelitian, maka penelitian ini juga termasuk dalam jenis penelitian sensus.

Sumber data penelitian ini menggunakan data primer dan data sekunder. Data primer diambil dari responden melalui kuesioner yang dibagikan pada Mahasiswa Pendidikan Ekonomi angkatan tahun 2014 Universitas Negeri Yogyakarta (untuk selanjutnya akan disebut UNY). Selain itu, data sekunder akan diperoleh dari data administrasi Pendidikan Ekonomi UNY yaitu mengenai jumlah mahasiswa yang menjadi subjek penelitian. Jumlah responden dalam penelitian ini adalah 69 mahasiswa. 
Prosedur dalam penelitian ini adalah membuat instrumen penelitian yang kemudian dilakukan uji coba penelitian terlebih dahulu dengan responden berjumlah 30 orang. Setelah itu, data yang diperoleh dari uji instrumen tersebut dianalisis dengan uji validitas dan reliabilitas. Jika instrumen penelitian dikatakan layak, selanjutnya mengambil data penelitian pada subjek penelitian.

Penelitian ini menggunakan tes, dan kuesioner sebagai metode pengumpulan data. Dalam melaksanakan metode tes digunakan untuk memperoleh data tentang pemahaman prinsip tabungtan syariah, sedangkan metode kuesioner digunakan untuk memperoleh data tentang tingkat religiusitas, faktor sosial budaya, persepsi tentang Bank Syariah, dan niat menabung di Bank Syariah.

Teknik analisis data yang digunakan dalam penelitian ini adalah analisis deskriptif, uji prasyarat analisis, uji hipotesis, dan menghitung sumbangan relatif dan sumbangan efektif. Analisis deskriptif digunakan untuk menganalisis data yang diperoleh dari responden melalui angket yang telah diisi, kemudian disajikan dalam bentuk deskripsi data masing-masing variabel. Deskripsi data yang digunakan meliputi statistik deskrisi, deskripsi karakteristik responden, dan deskripsi variabel penelitian. Selain itu, uji prasyarat analisis regresi meliputi uji linearitas, uji multikolinearitas, dan uji heteroskedastisitas. Uji hipotesis yang digunakan adalah regresi linier berganda.

\section{HASIL DAN PEMBAHASAN}

Pada penelitian ini, analisis deskripsi data yang disajikan yaitu nilai Mean (M), Median (Me), Modus (Mo), Standar Deviasi (SD), Rentang (Range), Nilai maksimal, dan Nilai minimal. Data penelitian ini meliputi data mengenai Pemahaman Prinsip Tabungan Syariah, Tingkat Religiusitas, Faktor Sosial Budaya, Persepsi tentang Bank Syariah, dan Niat Menabung di Bank Syariah. Hasil deskripsi data pada penelitian ini ditunjukkan pada tabel 1 .

Tabel 1. Deskripsi Data Penelitian

\begin{tabular}{lccccc}
\hline Deskripsi & $\begin{array}{c}\text { Pemahaman } \\
\text { Prinsip Tabungan } \\
\text { Syariah }\end{array}$ & $\begin{array}{c}\text { Tingkat } \\
\text { Religiusitas }\end{array}$ & $\begin{array}{c}\text { Faktor Sosial } \\
\text { Budaya }\end{array}$ & $\begin{array}{c}\text { Persepsi } \\
\text { tentang Bank } \\
\text { Syariah }\end{array}$ & $\begin{array}{c}\text { Niat } \\
\text { Menabung di } \\
\text { Bank Syariah }\end{array}$ \\
\hline $\mathrm{N}$ & 69 & 69 & 69 & 69 & 69 \\
Mean & 60,36 & 31,16 & 29,77 & 29,65 & 31,16 \\
Median & 60 & 31 & 29 & 30 & 32 \\
Modus & 65 & 31 & 29 & 29 & 35 \\
Range & 40 & 11 & 10 & 12 & 17 \\
Maksimum & 80 & 36 & 35 & 36 & 39 \\
Minimum & 40 & 25 & 25 & 24 & 22 \\
Std. Deviasi & 9,789 & 2,200 & 2,590 & 2,519 & 3,557 \\
\hline
\end{tabular}

Tabel 1 deskripsi data penelitian di atas menunjukkan bahwa variabel Pemahaman Prinsip Tabungan Syariah, Tingkat Religiusitas, Faktor Sosial Budaya, Persepsi tentang Bank Syariah, dan Niat Menabung di Bank Syariah masing-masing memiliki skor maksimum sebesar 80, 36, 35, 36, dan 39. Hal ini berarti bahwa skor tertinggi pada masing-masing variabel tersebut yang dimiliki oleh responden adalah $80,36,35,36$, dan 39 . Skor minimum masing-masing variabel sebesar 40, 25, 25, 
24, dan 22 yang berarti bahwa nilai terendah pada kelima variabel tersebut yang dimiliki oleh responden penelitian ini adalah 40, 25, 25, 24, dan 22. Angka range pada varibael-variabel tersebut sebesar 40,11, 10, 12, dan 17 yang merupakan selisih skor antara skor tertinggi (maksimum) dan skor terendah (minimum).

Selain itu, untuk nilai Mean pada variabel Pemahaman Prinsip Tabungan Syariah menunjukkan angka sebesar 60,36 yang berarti bahwa skor Pemahaman Prinsip Tabungan Syariah yang dimiliki oleh responden secara keseluruhan memiliki rata-rata sebesar 60,36. Nilai mediannya menunjukkan angka sebesar 60 yang berarti bahwa nilai tengah dari Pemahaman Prinsip Tabungan Syariah sebesar 60. Besarnya nilai modus menunjukkan angka sebesar 65 memiliki arti bahwa skor Pemahaman Prinsip Tabungan Syariah yang mempunyai jumlah terbanyak dalam distibusi yaitu 65. Angka standar deviasi sebesar 9,879 berarti bahwa tingkat penyebaran data penelitian pada variabel ini mencapai 9,879. Begitu pula dengan variabel lainnya.

Berdasarkan data yang telah didapat selama pengumpulan data, maka deskripsi karakteristik responden akan dijabarkan secara rinci berdasarkan kelas yang disajikan dalam bentuk tabel 2 .

Tabel 2. Distribusi Frekuensi Responden Menurut Kelas

\begin{tabular}{ccc}
\hline Kelas & F & Presentase \\
\hline U 2014 & 15 & $21,74 \%$ \\
A 2014 & 29 & $42,03 \%$ \\
B 2014 & 25 & $36,23 \%$ \\
\hline Jumlah & 69 & $100,00 \%$ \\
\hline
\end{tabular}

Sumber: data administrasi Prodi Pendidikan Ekonomi 2017, diolah

Berdasarkan informasi pada tabel 2, jumlah responden yang berasal dari Kelas U 2014 adalah sebanyak 15 responden (21,74\%), Kelas A 2014 sebanyak 29 responden (42,03\%), dan Kelas B 2014 sebanyak 25 responden (36,23\%). Oleh karena itu, dapat disimpulkan bahwa mayoritas Mahasiswa Pendidikan Ekonomi FE Angkatan Tahun 2014 UNY yang menjadi responden berasal dari Kelas A.

Selain itu, berdasarkan data yang diperoleh melalui jawaban responden menunjukkan bahwa variabel Niat Menabung di Bank Syariah yang masuk dalam kategori tinggi sebanyak 22 (31,81\%), kategori sedang sebanyak $41(59,42 \%)$, dan kategori rendah sebanyak $6(8,70 \%)$. Kecenderungan variabel Niat Menabung di Bank Syariah berada pada kategori sedang.

Pada variabel Pemahaman Prinsip Tabungan Syariah yang masuk dalam kategori sangat baik sebanyak $16(23,19 \%)$, kategori cukup baik sebanyak 38 (55,07\%), dan kategori kurang baik sebanyak 15 (21,74\%). Kecenderungan variabel ini berada pada kategori cukup baik. Kemudian, pada variabel Tingkat Religiusitas yang masuk dalam kategori sangat baik sebanyak 18 (26,09\%), kategori cukup baik sebanyak $45(65,22 \%)$, dan kategori kurang baik sebanyak $6(8,70 \%)$. Kecenderungan variabel Tingkat Religiusitas berada pada kategori cukup baik.

Selanjutnya, pada variabel Faktor Sosial Budaya yang masuk dalam kategori sangat baik sebanyak 17 (24,64\%), kategori cukup baik sebanyak 30 (43,48\%), dan kategori kurang baik sebanyak 22 (31,88\%). Kecenderungan variabel Faktor Sosial Budaya berada pada kategori cukup baik. Pada variabel Persepsi tentang Bank Syariah menunjukkan bahwa responden yang masuk dalam kategori sangat baik sebanyak 11 (15,94\%), kategori cukup baik sebanyak $38(55,07 \%)$, dan kategori kurang baik sebanyak 20 (28,99\%). Hasil dalam perhitungan menunjukkan mean sebesar 29,65 yang berarti rata-rata skor yang dimiliki oleh responden pada variabel ini terletak pada kelas interval 28,00-32,00. Oleh karena itu, dapat disimpulkan bahwa kecenderungan variabel Persepsi tentang Bank Syariah berada pada kategori cukup baik. 
Dalam penelitian ini, berdasarkan hasil perhitungan regresi ganda dan uji korelasi product moment (pearson), besarnya nilai SR dan SE dapat dilihat pada tabel di bawah ini.

Tabel 3. Ringkasan Sumbangan Relatif (SR) dan Sumbangan Efektif (SE)

\begin{tabular}{cccc}
\hline \multirow{2}{*}{ No } & \multirow{2}{*}{ Variabel } & \multicolumn{2}{c}{ Sumbangan } \\
\cline { 2 - 4 } & Pemahaman Prinsip Tabungan Syariah & $25,78 \%$ & Efektif (SE) \\
\hline 1 & Tingkat Religiusitas & $11,97 \%$ & $18,77 \%$ \\
2 & Faktor Sosial Budaya & $30,99 \%$ & $8,71 \%$ \\
3 & Persepsi tentang Bank Syariah & $31,26 \%$ & $22,56 \%$ \\
4 & Jumlah & $100,00 \%$ & $22,76 \%$ \\
\hline
\end{tabular}

Sumbangan relatif (SR) Pemahaman Prinsip Tabungan Syariah sebesar 25,78\%, pengaruh Tingkat Religiusitas sebesar 11,97\%, pengaruh Faktor Sosial Budaya sebesar 30,99\%, dan pengaruh Persepsi tentang Bank Syariah sebesar 31,26\% terhadap Niat Menabung di Bank Syariah pada Mahasiswa Pendidikan Ekonomi angkatan tahun 2014 UNY. Selain itu, sumbangan efektif (SE) Pemahaman Prinsip Tabungan Syariah sebesar 18,77\%, pengaruh Tingkat Religiusitas sebesar 8,71\%, pengaruh Faktor Sosial Budaya sebesar 22,56\%, dan pengaruh Persepsi tentang Bank Syariah sebesar 22,76\% terhadap Niat Menabung di Bank Syariah pada Mahasiswa Pendidikan Ekonomi angkatan tahun 2014 UNY. Dapat diketahui pula bahwa secara bersama-sama (simultan) variabel Pemahaman Prinsip Tabungan Syariah, Tingkat Religiusitas, Faktor Sosial Budaya, dan Persepsi tentang Bank Syariah sebesar 72,80\% terhadap Niat Menabung di Bank Syariah pada Mahasiswa Pendidikan Ekonomi angkatan tahun 2014 UNY, sedangkan sebesar 27,20\% dipengaruhi oleh variabel-variabel lain yang tidak diteliti dalam penelitian ini.

Hasil penelitian ini mendukung hipotesis pertama bahwa Pemahaman Prinsip Tabungan Syariah (X1) memiliki pengaruh terhadap Niat Menabung di Bank Syariah pada Mahasiswa Pendidikan Ekonomi angkatan tahun 2014 UNY (Y). Hal ini ditunjukkan dengan nilai koefisien regresi X1 sebesar 0,461 yang menyatakan bahwa setiap peningkatan Pemahaman Prinsip Tabungan Syariah sebesar 1 poin maka akan meningkatkan Niat Menabung di Bank Syariah pada Mahasiswa Pendidikan Ekonomi angkatan tahun 2014 UNY sebesar 0,461 satuan dengan asumsi variabel lainnya tetap yang berarti menunjukkan arah model yang positif. Selain itu, juga diperoleh nilai thitung sebesar 2,519 dengan signifikansi sebesar 0,014 pada taraf signifikansi $5 \%$ atau lebih kecil dari 0,05 .

Berdasarkan hasil pengujian secara parsial pengaruh Tingkat Religiusitas (X2) terhadap Niat Menabung di Bank Syariah pada Mahasiswa Pendidikan Ekonomi angkatan tahun 2014 UNY (Y) diperoleh nilai koefisien regresi sebesar 0,309 yang menyatakan jika Tingkat Religiusitas meningkat sebesar 1 poin maka Niat Menabung di Bank Syariah pada Mahasiswa Pendidikan Ekonomi angkatan tahun 2014 UNY akan meningkat sebesar 0,461 satuan dengan asumsi variabel lainnya tetap yang berarti menunjukkan arah model yang positif. Selain itu, juga diperoleh nilai $t_{\text {hitung }}$ sebesar 2,728 dengan signifikansi sebesar 0,008 pada taraf signifikansi $5 \%$. Karena nilai signifikansi lebih kecil 0,05 maka mendukung hipotesis kedua bahwa Tingkat Religiusitas berpengaruh terhadap Niat Menabung di Bank Syariah pada Mahasiswa Pendidikan Ekonomi angkatan tahun 2014 UNY.

Hasil pengujian pada penelitian ini juga mendukung hipotesis ketiga bahwa Faktor Sosial Budaya (X3) berpengaruh terhadap Niat Menabung di Bank Syariah pada Mahasiswa Pendidikan Ekonomi angkatan tahun 2014 UNY (Y) yang dapat dilihat dari nilai koefisien regresi sebesar 0,442. Hal ini menyatakan bahwa setiap peningkatan Faktor Sosial Budaya sebesar 1 poin maka akan meningkatkan Niat Menabung di Bank Syariah pada Mahasiswa Pendidikan Ekonomi angkatan 
tahun 2014 UNY sebesar 0,442 satuan dengan asumsi variabel lainnya tetap yang berarti menunjukkan arah model yang positif. Tidak hanya itu, pada variabel ini diperoleh nilai $t_{\text {hitung }}$ sebesar 3,757 dengan signifikansi sebesar 0,000 pada taraf signifikansi $5 \%$ atau lebih kecil dari 0,0.5.

Dalam penelitian ini juga mendukung hipotesis keempat yaitu terdapat pengaruh antara Persepsi tentang Bank Syariah (X4) terhadap Niat Menabung di Bank Syariah pada Mahasiswa Pendidikan Ekonomi angkatan tahun 2014 UNY (Y). Hal ini dapat dilihat pada nilai koefisien regresi sebesar 0,438 yang menyatakan jika Persepsi tentang Bank Syariah meningkat sebesar 1 poin maka Niat Menabung di Bank Syariah pada Mahasiswa Pendidikan Ekonomi angkatan tahun 2014 UNY akan meningkat sebesar 0,438 satuan dengan asumsi variabel lainnya tetap yang berarti menunjukkan arah model yang positif. Selain itu, diperoleh pula nilai $t_{\text {hitung }}$ sebesar 3,272 dengan signifikansi sebesar 0,002 pada taraf signifikansi $5 \%$.

\section{SIMPULAN}

Terdapat pengaruh positif Pemahaman Prinsip Tabungan Syariah terhadap Niat Menabung di Bank Syariah pada Mahasiswa Pendidikan Ekonomi angkatan tahun 2014 UNY. Hal tersebut dapat ditunjukkan nilai koefisien regresi sebesar 0,461. Selain itu, juga diperoleh nilai thitung sebesar 2,519 dengan signifikansi sebesar 0,014 pada taraf signifikansi 5\%. Karena nilai signifikansi $<0,05$ maka dapat disimpulkan bahwa Pemahaman Prinsip Tabungan Syariah berpengaruh positif terhadap Niat Menabung di Bank Syariah pada Mahasiswa Pendidikan Ekonomi angkatan 2014 tahun UNY.

Terdapat pengaruh positif Tingkat Religiusitas terhadap Niat Menabung di Bank Syariah pada Mahasiswa Pendidikan Ekonomi angkatan tahun 2014 UNY. Hal tersebut dapat ditunjukkan nilai koefisien regresi sebesar 0,309. Selain itu, juga diperoleh nilai thitung sebesar 2,728 dengan signifikansi sebesar 0,008 pada taraf signifikansi 5\%. Karena nilai signifikansi $<0,05$ maka dapat disimpulkan bahwa Tingkat Religiusitas berpengaruh positif terhadap Niat Menabung di Bank Syariah pada Mahasiswa Pendidikan Ekonomi angkatan tahun 2014 UNY.

Terdapat pengaruh positif Faktor Sosial Budaya terhadap Niat Menabung di Bank Syariah pada Mahasiswa Pendidikan Ekonomi angkatan tahun 2014 UNY. Hal tersebut dapat ditunjukkan nilai koefisien regresi sebesar 0,442. Selain itu, juga diperoleh nilai $t_{\text {hitung }}$ sebesar 3,757 dengan signifikansi sebesar 0,000 pada taraf signifikansi 5\%. Karena nilai signifikansi $<0,05$ maka dapat disimpulkan bahwa Faktor Sosial Budaya berpengaruh positif terhadap Niat Menabung di Bank Syariah pada Mahasiswa Pendidikan Ekonomi angkatan tahun 2014 UNY.

Terdapat pengaruh positif Persepsi tentang Bank Syariah terhadap Niat Menabung di Bank Syariah pada Mahasiswa Pendidikan Ekonomi angkatan tahun 2014 UNY. Hal tersebut dapat ditunjukkan nilai koefisien regresi sebesar 0,438. Selain itu, juga diperoleh nilai thitung sebesar 3,272 dengan signifikansi sebesar 0,002 pada taraf signifikansi 5\%. Karena nilai signifikansi $<0,05$ maka dapat disimpulkan bahwa Persepsi tentang Bank Syariah berpengaruh positif terhadap Niat Menabung di Bank Syariah pada Mahasiswa Pendidikan Ekonomi angkatan tahun 2014 UNY.

Terdapat pengaruh Pemahaman Prinsip Tabungan Syariah, Tingkat Religiusitas, Faktor Sosial Budaya, dan Persepsi tentang Bank Syariah secara simultan terhadap Niat Menabung di Bank Syariah pada Mahasiswa Pendidikan Ekonomi angkatan tahun tahun 2014 UNY. Hal ini ditunjukkan dengan hasil uji $\mathrm{F}$ pada taraf signifikansi 5\% yang diperoleh nilai $\mathrm{F}_{\text {hitung }}$ sebesar 42,733 dengan nilai signifikansi $F$ sebesar 0,000 atau $F<0,05$. Selain itu, hasil pengujian regresi ganda menunjukkan bahwa koefisien determinasi $\left(\mathrm{R}^{2}\right)$ sebesar 0,728 atau $72,80 \%$ yang menunjukkan besarnya sumbangan relatif (SR) dari kedua variabel bebas terhadap variabel terikat. Sumbangan relatif (SR) tersebut memiliki arti bahwa Pemahaman Prinsip Tabungan Syariah, Tingkat Religiusitas, Faktor Sosial Budaya, dan Persepsi tentang Bank Syariah mempengaruhi 72,80\% Niat 
Menabung di Bank Syariah pada Mahasiswa Pendidikan Ekonomi angkatan tahun 2014 UNY sedangkan $27,20 \%$ dipengaruhi oleh variabel lain yang tidak diteliti dalam penelitian ini. Besarnya sumbangan efektif (SE) masing-masing variabel yaitu 18,77\% untuk variabel Pemahaman Prinsip Tabungan Syariah, 8,71\% untuk variabel Tingkat Religiusitas, 22,56\% untuk variabel Faktor Sosial Budaya, dan 22,76\% untuk variabel Persepsi tentang Bank Syariah.

\section{DAFTAR PUSTAKA}

Ajzen, I. (1991). The Theory of Planned Behavior. Jurnal of Organizational Behavior and Human Decision Processes, Vol. 50, 179 - 211

Arikunto, S. (2013). Manajemen Penelitian. Jakarta: PT. Rineka Cipta.

Ancok, D. \& Suroso, F.N. (1995). Psikologi Islami: Solusi Islam Atas Problem Problem Psikologi. Yogyakarta: Pustaka Pelajar.

Kotler, P. \& Keller, K.L. (2009). Manajemen Pemasaran Jilid 2. Jakarta: Erlangga.

Otoritas Jasa Keuangan. (2017). Statistik Perbankan Syariah 2017 September. (http://www.ojk.go.id/id/kanal/syariah/data-dan-statistik/statistik-perbankansyariah/Pages/Statistik-Perbankan-Syariah---September-2017.aspx). Diakses pada 19 Desember 2017.

Otoritas Jasa Keuangan. (2017). Statistik Perbankan Indonesia 2017 September. (http://www.ojk.go.id/id/kanal/perbankan/data-dan-statistik/statistik-perbankanindonesia/Documents/Pages/Statistik-Perbankan-Indonesia---September2017/SPI\%20September\%202017.pdf). diakses pada 19 Desember 2017.

Otoritas Jasa Keuangan. (27 Oktober 2017). Siaran Pers: Market Share Keuangan Syariah Capai 8 Persen. (http://www.ojk.go.id/id/berita-dan-kegiatan/siaran-pers/Pages/Siaran-Pers-MarketShare-Keuangan-Syariah-Capai-8-Persen.aspx). diakses pada 11 April 2017.

Toha, M. (2003). Perilaku Organisasi: Konsep Dasar dan Aplikasinya. Jakarta: PT Raja Grafindo Persada. 